\title{
THE EFFECT OF THE RATIO OF SHARING THICKNESS $(\lambda)$ ON ROUNDING WITH TAPERED LATHE PROCESS ON ALUMUNIUM 6061
}

\author{
Tomi Ari Setyanto
}

Department of Mechanical Engineering, Faculty of Engineering, University of Merdeka Malang

Email corresponding author:tomi.setyanto@student.unmer.ac.id

\begin{abstract}
This study aims to find the value of the $L / D$ gradient ratio, the value of the compression ratio of thick thickness ( $\lambda$ ) and roundness value. The method used in this study is an experiment with data collection on; spindle speed (n), cutting depth (a), angle ( $\alpha$ ), and tool corner radius (nsr) vary. The results achieved at an $L / D$ ratio of 3.28, cutting depth (a) $0.6 \mathrm{~mm}$, spindle rotation (n) $250 \mathrm{rpm}$, tool corner radius ( $\mathrm{nsr}$ ) $0.2 \mathrm{~mm}$ and a sharpness angle of $2.5^{\circ}$ experienced compression ratio the largest thick thickness $(\lambda)$ is 2.53 , while at the $2.62 \mathrm{~L} / \mathrm{D}$ ratio, the cutting depth (a) $0.2 \mathrm{~mm}$, spindle rotation (n) $500 \mathrm{rpm}$, tool corner radius (nsr) 0.2 $\mathrm{mm}$ and the steepness angle of $2.5^{\circ}$ experiences the lowest compression ratio of thick thickness ( $\lambda$ ) of 0.53 . With a large compression ratio of thick fur ( $\lambda)$ the roundness value will also be large, in the compression ratio of thick thickness ( $\lambda$ ) 2.53 get a roundness value of $1.3 \mu \mathrm{m}$. While the lowest roundness value of $0.5 \mu \mathrm{m}$ occurs in the compression ratio of thick thickness $(\lambda) 0.53$.
\end{abstract}

Keywords: Roundness, L/D Ratio, Growled thick compression ratio $(\lambda)$.

\section{INTROCUTION}

In the turning process, there are several parameters such as infeed speed, cutting speed, cutting depth, tool geometry and L / D ratio. All of these parameters have an effect on the final product such as surface roughness and also the shindness of a shaft.

Many components of machines or other equipment, especially rotating machine or equipment components, have round sections. A component with a cylindrical surface with a good roundness (according to the specified tolerance) is needed, this will relate to the function of the component. The role of roundness in the function of a component includes dividing the load equally, facilitating lubrication, determining rotation accuracy, determining component life and determining custom conditions (Rochim T., 2001).

Out of roundness is a type of defect (geometric) and is generally closely related to several other malformations, namely axis similarity, straightness, straightness and alignment.

A component with an ideal roundness is very difficult to make, so it can be ascertained that there will be a roundness in the component. Although visually the cross section of a component is round, if you enlarge it, you will see a roundness that occurs in that section. The limitations that exist in the manufacturing process make it unavoidable, so that the roundness that occurs must be tolerated within certain limits according to the purpose and function of the component.

According to the results of Yuniawan Eka Hari's research (2018) the ratio of the thickness of the furrow $(\lambda)$ is influenced by the cutting speed. The biggest compression of the thickness $(\lambda)$ of 2.53 occurs at a cutting speed of $11.99 \mathrm{~mm} / \mathrm{min}$ and is influenced by the large chisel angle (Kr).

According to Muhammad Yanis, 2010. Analysis of roundness profiles to 
determine geometric errors in component manufacturing using a cnc lathe. Department of Mechanical Engineering, Faculty of Engineering, Sriwijaya University. Out of roundness is a type of malformation (geometric) and can be used to detect several other malformations. This study aims to determine the geometric errors that occur in component manufacturing using a $\mathrm{CNC}$ lathe by measuring roundness profiles. The roundness value obtained will also be used to find other geometric error values, namely alignment, perpendicularity and geometric tolerance. From the test results, it was found that the largest geometric error (nonroundness) on average was $44.7 \mu \mathrm{m}$ that occurred in the outermost position of the support/grip. Other errors are an misalignment of $5.5 \mu \mathrm{m}$, misalignment of 4.5 $\mu \mathrm{m}$, and the largest fault tolerance is $6.4 \mu \mathrm{m}$. Thus the CNC lathes used are still capable of making accurate components in terms of geometric errors. The geometric error value is still below the tolerance value $(50 \mu \mathrm{m})$.

Based on the description of the research results above, the researcher tries to analyze the "The Effect of The Ratio of Sharing Thickness $(\lambda)$ on Rounding with Tapered Lathe Process on Alumunium 6061”.

\section{METHODOLOGY}

The research methodology used is experimental method. The experimental research method is to make observations to find cause and effect data in a process through experiments so that you can find out the roundness that occurs.

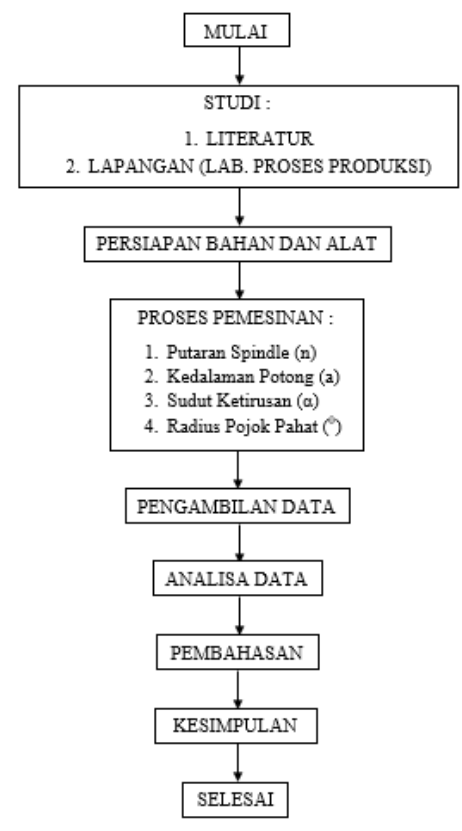

Figure 1. Research Flowchart

\section{Variables of Research}

Variables that determined:

1. Spindle turn (n).

2. Tend angle $(\alpha)$.

3. Cutting depth (a).

4. L/D ratio

Variables that observed:

1. Grunt Compression Ratio $(\lambda)$.

2. Roundness $(\mu \mathrm{m})$.

\section{Workpiece Material and Dimensions}

The material used is aluminum 6061. As shown in Figure 2. Length of specimen (L) $125 \mathrm{~mm}$ Diameter (D) $21 \mathrm{~mm}$.
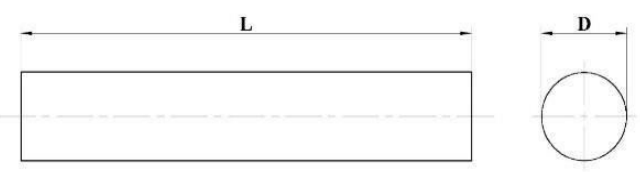

Figure 2. Dimension of Workpiece 


\section{Tools used}

1. Conventional lathes for machining processes

2. A caliper to measure the length and dimensions of the workpiece

3. Laptop Toshiba Satellite C640

4. Dial indicator.

\section{Research process design}

This test determines cutting parameters consisting of: spindle rotation, chisel corner radius, taper angle, and depth of cut. By varying these parameters, it can be seen the effect of the ratio of compression thickness $(\lambda)$ on roundness.

The research process design is shown in Table 1.

\section{Table 1. Research Process Design}

\begin{tabular}{|c|c|c|c|c|c|c|c|}
\hline No & \multirow{2}{*}{$\begin{array}{c}\text { Putaran } \\
(\mathbf{r p m})\end{array}$} & $\begin{array}{c}\text { nsr } \\
(\mathbf{m m})\end{array}$ & $\begin{array}{c}\text { Sudut } \\
\left({ }^{\circ}\right)\end{array}$ & $\begin{array}{c}\text { Kedalaman } \\
\text { Potong } \\
(\mathbf{m m})\end{array}$ & $\mathbf{l d}$ & \multicolumn{2}{|c|}{ Respon } \\
\hline 1 & & & & & & $\begin{array}{c}\text { Rasio } \\
\text { Pemampatan }\end{array}$ & $\begin{array}{c}\text { Kebulatan } \\
(\mu \mathrm{m})\end{array}$ \\
\hline 2 & & & & & & & \\
\hline 3 & & & & & & & \\
\hline 4 & & & & & & & \\
\hline 5 & & & & & & & \\
\hline 6 & & & & & & & \\
\hline 7 & & & & & & & \\
\hline 8 & & & & & & & \\
\hline 9 & & & & & & & \\
\hline 10 & & & & & & & \\
\hline 11 & & & & & & & \\
\hline 12 & & & & & & & \\
\hline
\end{tabular}

\section{DISCUSSION}

The data used in the study were taken based on the results of the taper turning process using aluminum 6061 which was carried out in the production process laboratory of the Department of Mechanical Engineering, Merdeka University, Malang, as shown in Table 1.In this study, the results of the response of two variables were the compression ratio of the thickness of the snarl $(\lambda)$. and roundness in terms of the tapered lathe process. Table 2 shows the results of tapered lathe process data retrieval which is then analyzed and discussed.

Table 2. Results of Data Collection for Tapered Lathe

\begin{tabular}{|c|c|c|c|c|c|c|c|c|c|}
\hline \multirow{3}{*}{ No } & \multirow{3}{*}{$\begin{array}{c}\text { Putaran } \\
\text { (rpm) } \\
\text { n }\end{array}$} & \multirow{3}{*}{$\begin{array}{c}\text { Radius } \\
\text { Pojok } \\
\text { Pahat } \\
\text { (mm) } \\
\text { nsr }\end{array}$} & \multirow{3}{*}{$\begin{array}{c}\text { Sudut } \\
\left(\begin{array}{c}() \\
\alpha\end{array}\right.\end{array}$} & \multirow{3}{*}{$\begin{array}{c}\text { Kedalaman } \\
\text { Potong } \\
\text { (mm) } \\
\text { a }\end{array}$} & \multirow{3}{*}{ /d } & \multicolumn{4}{|c|}{ Respon } \\
\hline & & & & & & \multirow{2}{*}{$\begin{array}{c}\text { Rasio } \\
\text { Pemampatan } \\
\text { Tebal Geram } \\
\text { (ג) }\end{array}$} & \multicolumn{3}{|c|}{$\begin{array}{l}\text { Kebulatan Pada } \\
\text { Titik }\end{array}$} \\
\hline & & & & & & & $\underset{(\mu \mathrm{m})}{\mathbf{A}}$ & $\begin{array}{c}\mathrm{B} \\
(\mu \mathrm{m})\end{array}$ & $\underset{(\mu \mathrm{m})}{\mathrm{C}}$ \\
\hline 1 & \multirow{3}{*}{250} & \multirow{3}{*}{0,2} & \multirow{3}{*}{2,5} & 0,2 & 2,70 & 0,73 & 1,45 & 1,68 & 1,45 \\
\hline 2 & & & & 0,4 & 2,83 & 1,12 & 1,69 & 1,69 & 1,53 \\
\hline 3 & & & & 0,6 & 3,28 & 2,53 & 1,78 & 2,18 & 2,24 \\
\hline 4 & \multirow{3}{*}{350} & \multirow{3}{*}{0,4} & \multirow{3}{*}{ ( } & 0,2 & 3,21 & 0,71 & 1,55 & 1,56 & 1,48 \\
\hline 5 & & & & 0,4 & 3,29 & 1,34 & 1,65 & 1,44 & 1,45 \\
\hline 6 & & & & 0,6 & 3,37 & 2,47 & 1,39 & 1,36 & 1,40 \\
\hline 7 & \multirow{3}{*}{500} & \multirow{3}{*}{0,2} & \multirow{3}{*}{2,5} & 0,2 & 2,62 & 0,53 & 1,48 & 1,54 & 1,58 \\
\hline 8 & & & & 0,4 & 2,80 & 1,02 & 1,55 & 1,61 & 1,58 \\
\hline 9 & & & & 0,6 & 3,15 & 2,05 & 1,13 & 1,31 & 1,25 \\
\hline 10 & \multirow{3}{*}{900} & \multirow{3}{*}{0,4} & \multirow{3}{*}{5} & 0,2 & 3,05 & 0,74 & 1,94 & 1,86 & 1,71 \\
\hline 11 & & & & 0,4 & 3,26 & 1,43 & 1,69 & 1,71 & 1,84 \\
\hline 12 & & & & 0,6 & 3,33 & 1,95 & 1,56 & 1,63 & 1,50 \\
\hline
\end{tabular}

The results of data processing the compression ratio of the thickness of the $\operatorname{snarl}(\lambda)$

$\lambda=\frac{h_{c}}{h}$

Where:

$\mathrm{h}_{\mathrm{c}}=$ growled thick after cutting $(\mathrm{mm})$

$\mathrm{h}=$ growled thick before cutting $(\mathrm{mm})$.

Spindel (n) $250 \mathrm{rpm}$,

$\mathrm{h}=\mathrm{f} \mathrm{x} \sin \mathrm{Kr}(\mathrm{mm})$

$\mathrm{h}=0,12 \mathrm{x} \sin 90$

$\mathrm{h}=0,12 \times 1$

$\mathrm{h}=0,12 \mathrm{~mm}$.

$\lambda_{1}=\frac{h_{c}}{h}$

$\lambda_{1}=\frac{0,087}{0,12}=0,73 \mathrm{~mm}$

Table 3 analyzes the compression ratio of the thickness of the rake ( $\lambda$ ) which is a characteristic of the machining process which is influenced by the workpiece material, the type of chisel, the angle of the tool, the cutting speed, the feeding speed, and the use of coolant. The thickness of the rake before cutting (h) and the thickness of the rake after cutting (hc) are not necessarily the same because they are influenced by the angle of rake, the speed of cutting and the material of the workpiece. In practice, the thickness of the cut after cutting (hc) must be greater than the thickness of the cut before cutting $(h)<1$ and this corresponds to a cutting depth of 0.4 
$\mathrm{mm}$ and $0.6 \mathrm{~mm}$, whereas at a cutting depth of $0.2 \mathrm{~mm}$ this occurs. which should be the thickness of the cut before cutting (h) is greater than the thickness of the cut after cutting (hc)

Table 3 The Result of the Thickness Compression Ratio

\begin{tabular}{|c|c|}
\hline$N_{0}$ & $\begin{array}{c}\text { Rasio } \\
\text { Pemamputan } \\
\text { tebal geram ( } \boldsymbol{\lambda})\end{array}$ \\
\hline 1 & 0,73 \\
\hline 2 & 1,12 \\
\hline 3 & 2,53 \\
\hline 4 & 0,71 \\
\hline 5 & 1,34 \\
\hline 6 & 2,47 \\
\hline 7 & 0,53 \\
\hline 8 & 1,02 \\
\hline 9 & 2,05 \\
\hline 10 & 0,74 \\
\hline 11 & 1,43 \\
\hline 12 & 1,95 \\
\hline
\end{tabular}

\section{Radar Graph Analysis Results}

In Table 3, the results of the Tapered Lathe Data Retrieval are shown, then a radar graph is made, this is used to analyze the roundness error rate shown in Figure 3.

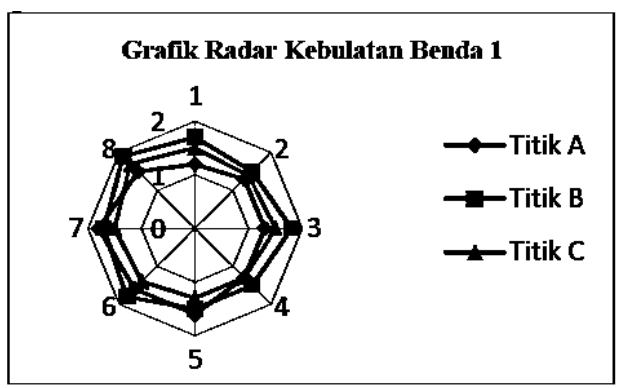

Figure 3. Round Object Radar Graph 1

Radar Graph of Object Roundness 1 with rotation (n) $250 \mathrm{rpm}$, tool corner radius (nsr) $0.2 \mathrm{~mm}$, taper angle $2.5^{\circ}$, and depth of cut $0.2 \mathrm{~mm}$ showing the maximum radar graph at point B point 8: $1,9 \mu \mathrm{m}$ and minimum at point A point 1: 1,2 $\mu \mathrm{m}$.

Minimum area of circle (MZC): radius of max circle - radius of circle min.

$\mathrm{MZC}=1,9 \mu \mathrm{m}-1,2 \mu \mathrm{m}$.
$\mathrm{MZC}=0,7 \mu \mathrm{m}$

The roundness of object 1 is $0.7 \mu \mathrm{m}$.

\section{The Effect of L / D Tendency Ratio to}

\section{Compression Ratio of Fur Thickness $(\lambda)$}

From Table 2, a graph of the comparison between the L/D taper ratio and the thickness ratio of the grinding wheel is shown in Figure 4.

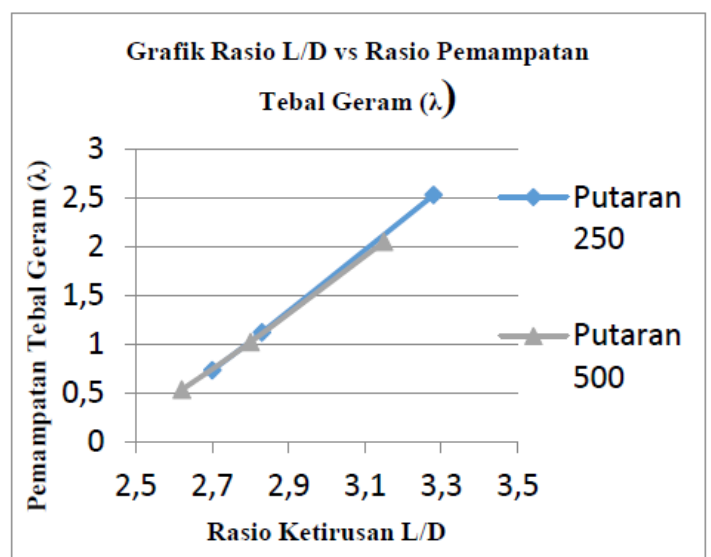

Figure 4. Graph of the Effect of L/D Slope Ratio on Compression Ratio of Thickness of $\operatorname{Fur}(\lambda)$.

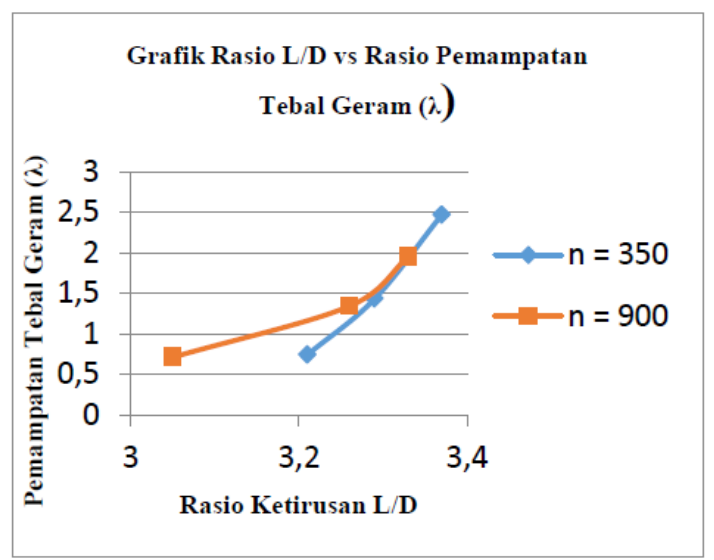

Figure 5. Graph of the Effect of L/D Slope Ratio on Compression Ratio of Fur Thickness ( $\lambda$ ).

Based on Figures 4 and 5, it can be seen that the effect of the $\mathrm{L} / \mathrm{D}$ taper ratio on the compression ratio of snarl thickness $(\lambda)$. The greater the value of the L/D taper ratio, the greater the value of the compression thickness $(\lambda)$, this is due to the larger the diameter of the lathe, the greater the cutting 
width (b). With this the thickness of the cut before cutting becomes small because the thickness of the cut before cutting is inversely proportional to the cutting width (b) is indicated by the formula: $\mathrm{h}=\mathrm{A} / \mathrm{b}$. With the value of the thickness of the grinding before cutting (h) is small, the density ratio of the thickness of the grinding is large.

\section{Effect of Compression Ratio of Thickness of Grinding $(\lambda)$ on Roundness}

Based on Table 4, the ratio of the compression of the thickness of the snarl $(\lambda)$ and the roundness is made a graph of the effect of the ratio of the thickness of the incision $(\lambda)$ to the roundness shown in Figures 6 and 7.

Table 5. Ratio of Compression Thickness of Roar $(\lambda)$ and Roundness

\begin{tabular}{|c|c|c|}
\hline No & $\begin{array}{c}\text { Rasio } \\
\text { Pemampatan } \\
(\boldsymbol{\lambda})\end{array}$ & $\begin{array}{c}\text { Kebulatan } \\
(\boldsymbol{\mu m})\end{array}$ \\
\hline 1 & 0,73 & 0,7 \\
\hline 2 & 1,12 & 0,9 \\
\hline 3 & 2,53 & 1,3 \\
\hline 4 & 0,71 & 0,6 \\
\hline 5 & 1,34 & 0,8 \\
\hline 6 & 2,47 & 1 \\
\hline 7 & 0,53 & 0,5 \\
\hline 8 & 1,02 & 0,6 \\
\hline 9 & 2,05 & 0,8 \\
\hline 10 & 0,74 & 0,5 \\
\hline 11 & 1,43 & 0,6 \\
\hline hart Area & 1,95 & 0,8 \\
\hline
\end{tabular}

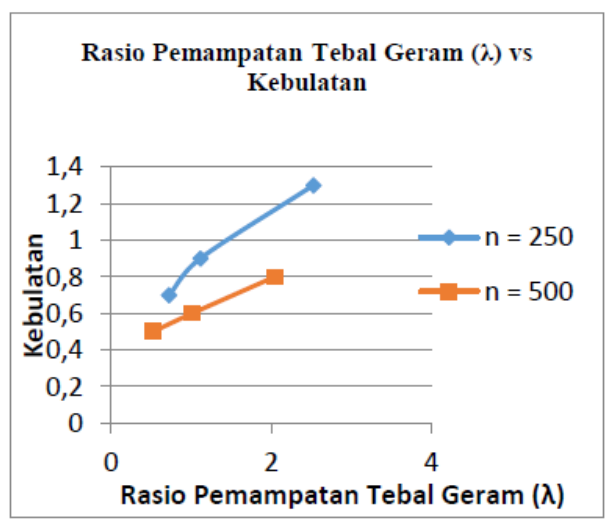

Figure 6 Graph of the Effect of the L/D Slope Ratio on the Compression Ratio of Thickness of Fur ( $\lambda)$.

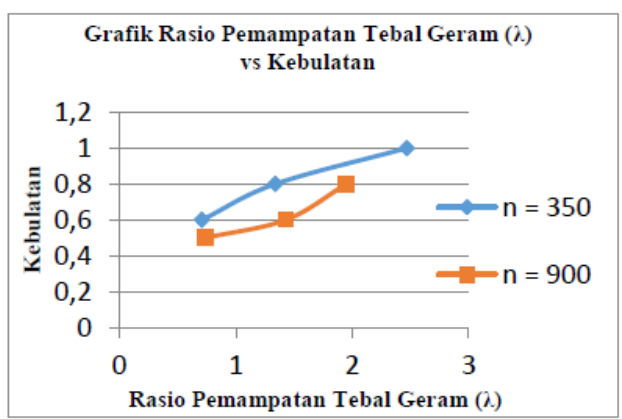

Figure 7. Graph of the Effect of L/D Slope Ratio on Compression Ratio of Fur Thickness (ג)

Figures 6 and 7 show that the sphericity of the lathe is influenced by the ratio of compression to the thickness of the rake $(\lambda)$. The greater the ratio of the thickness of the rivet $(\lambda)$, the greater the roundness that occurs. This is influenced by spindle rotation and tool angle, so it takes spindle rotation and the correct tool angle for each type of turning to get good roundness results. The depth of infeed also affects the roundness of the lathe.

\section{CONCLUSION}

The effect of the L / D taper ratio on the compression ratio of the thickness of the snarl $(\lambda)$. The greater the value of the L / D taper ratio (3.28), the greater the value of the compression thickness $(\lambda)(2.53)$, this is due to the larger the diameter of the lathe, the greater the cutting width (b). The roundness of the lathe that occurs is influenced by the ratio of compression to the thickness of the snarl $(\lambda)$. The greater the ratio of the thickness of the rivet $(\lambda)$ (2.53) the greater the roundness $(1.3 \mu \mathrm{m})$ that occurs. 


\section{REFERENCES}

Arizal, 2013. Pengaruh Kecepatan dan Panjang Pemotongan terhadap Kebulatan poros S45C Proses Bubut Konvesional.

Ficky Hamdhani, 2014. Optimasi Pemesinan pada Mesin Bubut Tipe M-300 Horrison dengan Metode Optimasi Algoritma Genetika. Jurnal EDinamis, Volume.8, No.4.

Haris Eka Y, 2018. Analisa Umur Pahat dan Keausan Pahat Karbida Pembubutan Bahan Alumunium 6061 Dengan Menggunakan Mesin Bubut Konvensional. Skripsi Jurusan Teknik Mesin, Fakultas Teknik, Universitas Merdeka Malang.

Kalpakjian S, 1995. Manufacturing Process for Engineering and Technology. Addison Wesley Publishing Company.

Mariatanto Budi, 1996. Pengaruh kecepatan pemotongan dan gerak makan terhadap penyimpangan dan kebulatan produk hasil pemesinan cnc turn 242.

Muhammad Yanis, 2010. Analisis profil kebulatan untuk menentukan kesalahan geometric pada pembuatan komponen menggunakan mesin bubut cnc. Jurusan Teknik Mesin Fakultas Teknik Universitas Sriwijaya.

Rochim Taufiq, 1993. Teori Dan Teknologi Proses Pemesinan. Jurusan Mesin, Fakultas Teknologi Industri, ITB, Bandung.

Raul, 2016. Pengaruh Variasi Kecepatan Potong Dan Kedalaman Potong Pada Mesin Bubut Terhadap Tingkat Kekasaran Permukaan Benda Kerja ST 41. Jurnal Teknik Mesin, Tahun 24, No.1.

Sreejith, P. S and Ngoi, B. K. A. 2000. Dry Machining of The Future. School of Mechanical and Production Engineering. Nanyang Technology University Singapore.

Tata Surdia, Shinroku Saito, 1984. Pengetahuan Bahan Teknik. PT. Pradnya Paramita, Jakarta.

Wahyu Dwi A, 2013. Pengaruh Cutting Speed dan L/D Terhadap Keselindrisan Benda Kerja Hasil Finishing Pada Proses Pembubutan Tirus Divergen dengan Alumunium 6061, Skripsi Jurusan Teknik Mesin,
Fakultas Teknik, Universitas Brawijaya, Malang. 